Удк 272-726.1:929 Степинац А., загребачки надбискуп 272-752-789.5(450)"1924/1931"

DOI https://doi.org/10.31212/tokovi.2018.3.dim.11-32

Оригинални научни рад

Примљен: 9. 10. 2018,

Прихваћен: 16. 11. 2018.

Ljubodrag DIMIĆ

Faculty of Philosophy in Belgrade

ljubodrag_dimic@yahoo.com

\title{
Alojzije Stepinac, Student of the Collegium Germanicum
} (1924-1931)

\begin{abstract}
The seven-year stay at the Collegium Germanicum (1924-1931) had a major influence on the ideological and religious maturation of Alojzije Stepinac. Education at this seminary for Roman Catholic priests, administered by the Jesuits, took place in circumstances of intensified clericalization of Croatian society and conflict between the Catholic Church and the Yugoslav state.
\end{abstract}

Key words: Alojzije Stepinac, Collegium Germanicum, Roman Catholic Church, Jesuits

Alojzije Stepinac was born in Brezarić, a village in the parish of Krašić, on the border of the former Jastrebarsko district and Žumberak, on 8 May 1898. The spirit of clericalism of the Roman Catholic Church had a direct formative influence on him. He was brought up in austerity and strict obligation to respect the principles of church and religion. His piety was also strengthened by the fact that there had already been several educated priests in his family. ${ }^{1}$ After a four-year elementary schooling, at the recommendation of a local parish priest, Stepinac was admitted to classical high school in Zagreb in 1908, boarding at the Archdiocese of Zagreb orphanage. During the years spent in Zagreb (1909-1916), the religiousness of Alojzi-

1 Dr. Matija Stepinac, the uncle of the father of A. Stepinac, was particularly important as a longtime priest in Zagreb's seminary and one of the candidates for the Archbishop of Zagreb. Stella Alexander, The Triple Myth: a Life of Archbishop Alojzije Stepinac, (Boulder/New York: Columbia University Press, 1987), 6, 7. 
je Stepinac was further enhanced. ${ }^{2}$ When he was in second grade, Dr. Josip Lončarić was appointed as the head of orphanage. In his work, Lončarić was guided by the lessons he had received during his formation and education at the Jesuit Collegium Germanicum and at the Pontifical Gregorian University in Rome. ${ }^{3}$ After completing sixth grade and intending to dedicate himself to the priesthood, Stepinac entered the archbishop's seminary at the Kaptol in 1915 with the intention of completing his last two classes and passing his matura exam. His conscription into the army, completion of 7 th grade, his expedited graduation (so-called "war matura"), and the months spent at military training in Karlovac following his recruitment in June 1916 and a condensed officer's course in Rijeka, changed his life significantly. At that time Stepinac had donned his priestly robes and was regularly dedicated to religious exercises. ${ }^{4} \mathrm{He}$ fought on the Italian front at Gorizia, in Pavia and the Soča River, was wounded in July 1918, and spent months in captivity. ${ }^{5}$ Stepinac later described his days on the first lines of the battlefront as "terrible and bitter hours." 6 On the front he saw the negative behavior of the chaplain, which for some time influenced a change in his attitude toward his future calling. ${ }^{7}$

Failure at agronomy studies, which he only took for one semester, and the breakup of his engagement with Marija Horvat several years later, had a significant impact on Alojzije Stepinac. His religious fervor, his activism in the work of the "Domagoj" society, his participation in the Catholic Croatian Eagles youth sport organization, his adherence to the ideas of the Catholic Action, his need to refrain from anything that is worldly, his willingness to sacrifice himself for faith, indicated the degree of his religious fanaticism. In such circumstances, the life choice of a priestly calling had been proposed to Stepinac in 1924 by his former professor and

2 The Archdiocese of Zagreb orphanage was founded by Archbishop Maksimilijan Vrhovec (1788-1828).

3 Benigar, Alojzije Stepinac, 36.

4 Benigar, Alojzije Stepinac, 39-40; Robin Harris, Stepinac, njegov život i vreme, (Zagreb: Školska knjiga, 2016), 45.

5 Harris, Stepinac, njegov životi vreme, 47-48.

6 E. Beluhan, „Da li je kardinal Stepinac bio zasut minom na bojištu?", Stepinac mu je ime, knj. I, (Zagreb: Kršćanska sadašnjost, 1991), 105; Benigar, Alojzije Stepinac, 49; Harris, Stepinac, njegov život i vreme, 46-47.

7 Stjepan Sirovec, Hrvati i Germanicum, (Zagreb: Filozofsko-teološki institut Družbe Isusove, 2004), 71. - According to Stepinac's statement to priest Vranekovic, the reason for this was: "After returning from the battlefield in 1919, I stood firmly on this view: in the theology no! I have seen many sad examples of priestly life and decided that it was better never to be a priest than to be like these sorry fellows." Harris, Stepinac, njegov život i vreme, 48. 
director of the institution where Dr. Josip Lončarić had lived. This was no accident, because Lončarić had been monitoring the life paths of his former students. He remained in contact with Stepinac during the latter's period on the front through letters, and after his return from the war, Alojzije visited him and told him he did not intend to pursue a clerical calling. This did not diminish Lončarićs resolve to sway Stepinac by "shaking up his conscience" and convincing him to become a priest. This was further reinforced by Lonarčić's text on St. Clement Mary Hofbauer, which conceived, as his author later claimed, with Alojzije Stepinac in mind. The cover letter, delivered together with the text published in the gazette Sacredos Christi, had the intention of bringing Stepinac into the priestly fold. Alojzije Stepinac himself later said that Lončarić's letter had impacted him like "a bolt from the blue," which "shook him up significantly" and produced a "great and difficult struggle," which lasted three weeks. ${ }^{8}$

The conversation that Alojzije Stepinac later had at one of the Eagles' sports events in Djakovo with his former professor, who had previously encouraged him to choose a life of service "in God's vineyard," was, in all likelihood, decisive in choosing his lifelong calling. ${ }^{9}$ Lončarić advised Stepinac to continue his studies at the Gregorian Jesuit University in Rome, the city that was "the center of Christianity." ${ }^{10}$ The seven-day spiritual exercises he had in Zagreb, with the Jesuits of Bruno Foretić, who had been his confessor since second grade of high school, also contributed to the search for and discovery of his life's calling. After these "spiritual exercises" Alojzije Stepinac, at the age of 26, decided in favor of the priesthood. He communicated his decision to Dr. Lončarić. ${ }^{11}$

The spirit of the intensified clericalization of Croatian society, which was felt after the formation of the Catholic Action, essentially turned

8 According to certain information, a relative, Matija Stepinac, a very respectable and influential theologian, a student of Theology Faculty in Innsbruck and one of the most serious candidates for the post of Archbishop of Zagreb after the death of Archbishop Mihalović, had a critical influence on Stepinac to become a priest. Ivan Cvitković, Ko je bio Alojzije Stepinac, (Sarajevo: Oslobođenje, 1986), 24; Harris, Stepinac, njegov život i vreme, 51.

9 A. Stepinac also stayed in touch with Lončarić during the war years on the Italian front. He was one of the most influential priests who, during the 1920s, was considered a possible successor to Archbishop A. Bauer. Danas, 1. 8. 1989, 64.

10 There are indications that Stepinac intended to study at Innsbruck, just as his cousin Matija Stepinac did, but that under the influence of Josip Lončarić, who himself was a Germanicum student (in the generation of 1891-1898), he opted for the Pontifical Gregorian University.

11 Sirovec, Hrvati i Germanicum, 72; Benigar, Alojzije Stepinac, 66-68. 
Stepinac in the direction of Rome. He was by no means a stranger to training in a Jesuit-administered institution whose religious, pedagogical and political influence had shaped him prior to 1916 and after 1918. His departure for the Collegium Germanicum was arranged with Rector Hoffmann by his high school colleague Nikola Kolarek, who at that time was a trainee at the college. Of particular importance was the recommendation of Dr. Lončarić, as well as the fact that the Rector had also been informed about Alojzije Stepinac through clergyman Matija Stepinac. The certificate of admission to the Collegium Germanicum was issued on October 7, 1924, by the general of Jesuit Order and it was handed to Alojzije Stepinac by Dr. Lončarić himself on October 15, 1924. Permission for study in Rome was also issued by Zagreb Archbishop Bauer. ${ }^{12}$ And so, several months after deciding to join the priesthood, Stepinac became a trainee of the Jesuit Collegium Germanicum and a student at the Pontifical Gregorian University. ${ }^{13}$ Later biographers of the archbishop's life among the ranks of the clergy emphasized that his path, like everything else about him, had been determined by "providence."

The Collegium Germanicum was established in 1552 by Pope Julius III (1550-1555) and Ignatius Loyola, founder of the Society of Jesus. The Rome-based college is a seminary for Roman Catholic priests from Germany, which was affected by the reformist movement of Martin Luther. ${ }^{14}$

12 Lončarić's letter to the Germanicum's rector, Hoffman, on October 3, 1924, contained six pages and detailed the biography of Alojzije Stepinac, with a note that his struggle for the choice of his life's calling had been going on for eight years. Benigar, Alojzije Stepinac, 68.

13 He traveled to Rome at the end of October 1924 with Jesuits Stjepan Sakač and Nikola Maslać, and for the next seven years he did not return to his homeland.

14 The college was founded by the papal bull "Dum sollicita" Juliana III from August 31,1552 , and began its work on October 28, 1552. The bull of Pope Gregory XIII "Ita sunt humana" merged Germanicum with the Hungaricum Institute in the institution "Papi Institut Germanicum et Hungaricum." With an allocation of a significant piece of land, this institution was financially secured and it was able to work unimpeded. A certain break in the work of the Germanicum was at the time of the ban imposed by Emperor Joseph II and the Napoleonic wars. The Work recommenced in 1818. Due to the temporary abolition of the Jesuit order in 1773 , the college was run by diocesan priests for a certain time. The college also did not work for a period of two years during the revolutionary year 1848 in Europe. Sirovec, Hrvati i Germanicum, 20-22; Martin Leitgö, Vom Seelenhirten zum Wegführer. Sondirungen zum Bischöflichen Selbstverständnis im 19. und 20. Jahrhundert. Die Antrittshirtenbriefe der Germaniker bis- 
Its intention was to bring up priests loyal to the Roman Catholic Church, intent on continuing to fight for the apostolate of the faith, devoted to the papacy and Rome, ready to oppose Protestantism and foster the spirit of the Counter-Reformation.

The bull "Ex Collegio Germanico", issued by Pope Gregory XIII on April 1, 1584, established new rules (constitutions) on the functioning of this institution. Out of a total of 74 paragraphs, 17 regulated the admission of students, 36 regulated discipline, 7 pertained to the duties of the rector, and 14 duties of the custodian. The "Constitutions" also contained the pledge of the Collegium Germanicum students to stay in Rome and its environs during their seven years of study (3 years of philosophy and 4 years of theology) and would not return to the city for a period of three years following the completion of their studies. Germanicum students were obliged not to join any religious order during the above period. From that same period, there was also the rule, which like all others, was in force at the time when Alojzije Stepinac was staying at the Germanicum, according to which the seven-year study of philosophy and theology ended with a "doctorate" (the so-called final exam - rigorosum). For the first 40 days, the prospective Germanicum students became acquainted with the Rules of the college, conducted weekly spiritual exercises, and made a lifetime confession. If they were physically and spiritually prepared to accept the Rules of the college, after six months of their arrival, they took a solemn oath. Since they entered the institution in October, the oath was always taken in May of the following year. The acceptance ceremony ended with the college's hymn "Laudate Dominum" and a "fraternal embrace," by which the students were "initiated" into the community of the Collegium Germanicum. ${ }^{15}$

After reopening in 1818, the "new" Germanicum was an institution for priestly upbringing and education. This is where they formed devoutness, modesty, discipline, "spiritual talent." Theological-philosophical knowledge was acquired, as in the previous period, at the Pontifical Gregorian University. The Gregorian University, like the Germanicum, worked according to the Jesuit program, and the professors were members of the Jesuit order. ${ }^{16}$ Within the Gregoriana there was a Faculty of Philosophy, a

chöfe (1837-1962), (Rim: Herder, 2004); Peter Schmidt, Das Collegium Germanicum in Rom und die Germaniker. Zur Funktion eines römischen Ausländerseminars (15521914, (Tübingen: Max Niemeyer Verlag, 1984). 
Faculty of Canon Law, a Faculty of Church History, a Biblical Institute (including the Biblical Faculty and the Ancient Near Eastern Faculty), an Oriental Institute (within it there were the Faculty of Eastern Church Science and Faculty of Eastern Church Law), Faculty of Missiology, Faculty of Sociology, as well as several other scientific institutes and centers where Christian spirituality was studied. Among them were the Academy and Seminar for Social Issues, which specifically studied the social problems of the areas from which the students hailed. ${ }^{17}$

In addition to academic knowledge, the everyday life of the students consisted of an ascetic life in the Ignatian spirit (according to the principles of Ignatius Loyola and the Jesuit order). Among the Germanicum students, there was, in general, a unity of stances and ideas, a similarity of views of the world, a pronounced attachment to Rome, a spiritual self-awareness stemming from their close bonds to the church, an apostolic Jesuit spirit and Ignatian piety and obedience to the pope. ${ }^{18}$ Staying at the Collegium Germanicum and studying at the Gregoriana were an important determinant of those who were scholars and students at the university. These institutions significantly influenced the formation of their own protégés and determined their uniqueness as a group. ${ }^{19}$ We should also add the fact that the very order that organized the Collegium Germanicum and the Gregorian University was "authoritative, unified and centralized, as in all good armies." The Jesuit order's course of action has not changed. It has respected its centuries-old tradition. There has been no place for "emocratic regulations" in its organization and functioning. All the power is concentrated in the hands of the "generals" of the order which appoints high officials, while the lower positions are determined by the local monks and provincials. The remaining members of the or-

17 In addition to the Gregorian University, considered to be the most distinguished Pontifical University, there are 6 papal universities, 10 autonomous church faculties and high theological schools, 58 colleges for priest candidates, 137 schools for monks, 12 for nuns, and 6 for lay students. Sirovec, Hrvati i Germanicum, 57-58.

18 I. Loyola envisaged three degrees of obedience to the pope: "The lowest and most imperfect degree of obedience is the one in which we execute externally issued orders. Such obedience does not deserve to be called virtue if it does not rise to the second degree, at which the will of our superior is confirmed not only by doing his will, but also by the tendency to express it in the way that we both want or do not want the same thing. If we want the same, then it is the second degree of obedience. And the third degree of obedience would be for those who want to sacrifice themselves completely to God. Then, in addition to their will, they have to sacrifice their thoughts, so they have not only the same will, but also the same opinion, just like the superior." Petar S. Leposavić, Papstvo, (Beograd: Izdavački grafički atelje „M“, 2005), 442. 
der (soldiers) had to obey and always be ready "for battle and sacrifice". "There is not very much reservation there, or rights. Where his superiors need him, the Jesuit will go; immediately, without question and without hesitation, without any explanation or discussion; from one place to another; from one service to another; from lower to higher and from higher to lower. As demanded a by higher, general interest..." ${ }^{20}$

A characteristic of all the scholars and students of the Collegium Germanicum and the Gregorian University was that they retained their group awareness after returning to their homeland. Maintaining a "common spirit" and information was the result of a special institution of "correspondence" between former students and trainees, established in 1892, becoming a tradition of sorts, but also as an obligation honored by the graduates. In the Germanicum, over time, there was a merging of two influences - the papacy, which sought to form a reliable clergy and leading people in the church, and the Jesuits, who sought to create good theologian scholars, mobile priests and dedicated pastors. ${ }^{21}$

After the end of the First World War, education in the Germanicum was not only an honor, but also gave its students a significant advantage in their careers. It can be said that in the 20th century, the students and scholars of the Germanicum were massively present in high ecclesiastical positions. In their own environments, the students of the Collegium Germanicum and the Gregorian University were considered not only highly educated and qualified priests, but also agents and advocates of "Roman centralism" within local church organizations. This was an important institution that had a very strategic place between the center in the Vatican and Catholicism in the countries from which the students came to Rome. ${ }^{22}$

Alojzije Stepinac belonged to the fourth generation of students of the "new" Germanicum, born in the years between 1885 and 1917 and educated in the period from 1907 to 1944. Just as the highest church prelates belonged to the elderly (third) generation of students, so those from the student generation of A. Stepinac largely belonged to lower social classes and came from rural families with several children. ${ }^{23}$ That was a significant change brought that happened at the end of the 19th and the beginning of the 20th century. Another characteristic that applied to the stu-

20 Katolički tjednik, br. 29, rujan 1940.

21 Leitgö, Vom Seelenhirten zum Wegführer, 30.

22 Schmidt, Das Collegium Germanicum in Rom, 1.

23 The third generation of Germanicum students consisted of those born between 1864 and 1882 and educated at the college from 1884 to 1910. Individuals from this generation became bishops in the interwar years. 
dents from those generations who had achieved the title of bishop was rapid advancement. The generations that were educated at the same time as Stepinac were "more international" than their predecessors, which was, inter alia, the result of an intensive growth of the number of Jesuit provinces and membership during the when the general of the Jesuit order was Wladimir Ledóchowski. ${ }^{24}$

Stepinac spent seven years at the Jesuit Collegium Germanicum (1924-1931) and obtained two doctoral degrees - in theology and philosophy. His study of scholastic philosophy lasted three and theology four years. In the Germanicum he was ordained on October 26, 1930. The manuductor at Stepinac's "first mass" in Rome, which he served in the Basilica of Saint Paul Outside the Walls, was Dr. Josip Lončarić. The text that he chose for the motto of his mass was a verse from St. Paul to the Galatians 6:14, which said: "But as for me, may I never boast, except in the cross of our Lord Jesus Christ, through which the world has been crucified to me, and I to the world."25 The fact that five out of the 26 students in his generation went on to become bishops, followed a few generations later by 17 more future bishops, shows just how influential the school was.

Stepinac's biographers point out that during the years spent at the Gregorian University, he showed diligence, obedience, dedication, maturity, responsibility, physical readiness, simplicity, asceticism. Allegedly he was a "faithful son of the Croatian people who, through all the trials and tribulations in the course of history, remained loyal to the Pope." ${ }^{26}$ Some of his schoolmates from the Germanicum recalled later that A. Stepinac, more than others, read Catholic magazines and newspapers, extracted suitable material from them in preparing himself for his future work as a pastor. ${ }^{27}$ It has also been recorded that he sometimes assisted the priest during

24 Leitgö, Vom Seelenhirten zum Wegführer, 157.

Ledóchowski was at the head of the "Society of Jesus" 27 years (1915-1942). In that period, the number of provinces increased from 27 to 50, and the number of members of the Jesuit order grew from 16,946 to 26,588. The Jesuit order conducted 15 universities of 420 independent colleges, with 139,000 students. Alojzije Stepinac, in the years when he was a coadjutor bishop and later archbishop of Zagreb, contributed most directly to this growth. Sirovec, Hrvati i Germanicum, 22.

25 Alexander, The Triple Myth, 12-14; Stjepan Sakač, „Barbara Stepinac i svećeničko zvanje njenog Alojzija“, Stepinac mu je ime, knj. I, (Zagreb: Kršćanska sadašnjost, 1991), 95-97; Sirovec, Hrvati i Germanicum, 72.

26 Vladimir Horvat, Kardinal Alojzije Stepinac - mučenik za ljudska prava, (Zagreb-Samobor-Krašić: Meridijani, 2008), 42-43; Zvonimir Gavranović, In Serch of Cardinal Stepinac. A Complete Biography, (Zagreb: Kršćanska sadašnjost, 2011), 61-67.

27 Benigar, Alojzije Stepinac, 328. 
"spiritual exercises" delivered to newly arrived students. For a while, he served a guide to a group of students during a visit to the most significant places of worship in Rome. In his spare time he liked to play handball. Because of his reticence, some students called him "the silent one," for he was not a man of "big and loud words." Like the other students, Stepinac also often reexamined his decision to study in Rome. He dismissed his doubts through prayer. His colleagues were particularly respectful of his piousness, his interesting sermons, "devotion" to the Pope and his "poised serenity". ${ }^{28}$ During the initial years of his study of philosophy, he listened to lectures in logic, ontology and theodicy, cosmology, ethics, history of philosophy, church law... No one mentions his grades. Nevertheless, it should be said that, unlike his fellow student Franjo Šeper, who had top grades, Stepinac was one of those students who did not excel in either grades or knowledge. He himself noted that he had always endeavored to pass his exams on time but was not very interested in grades.

Like all the other Germanicum students, Stepinac had his own room, which was arranged like a typical priestly cell. The furniture included a table, a chair, a bookshelf, a section for prayer, a bed, and a washba$\sin$. The rooms were not heated. There were "house rules" in the college, which had to be respected and which did not allow a student to cross the threshold of another student's room. The only ones who could do that were supervisors and students who were on special duty. The rules were strict, similar to those in monasteries. Because the Germanicum students wore red uniforms, Romans called them "fratri rossi." The students themselves looked after the cleanliness of their personal clothing, laundry, footwear and rooms. ${ }^{29}$

For all the students, including Alojzije Stepinac, the years spent at the Collegium Germanicum were a time of "spiritual maturation." The "charisma of the Collegium Germanicum" inevitably left its mark on all its students. According to the rules, every student, during the years spent in the Germanicum, was entrusted with responsible duties. No one issued commands because everyone knew their rights and obligations. First and foremost was piety. They insisted on "self-cultivation of the will and the heart." Attention was given to self-understanding and self-restraint, to rectifying existing weaknesses and identified errors, to deepening knowledge about the persona of Jesus Christ. They developed the skills of merging freedom with obligation and privacy with responsibility for the com-

28 Benigar, Alojzije Stepinac, 77-82; Harris, Stepinac, njegov život i vreme, 52-53.

29 Benigar, Alojzije Stepinac, 77-78. 
munity. Part of the spiritual exercises consisted of achieving the ability to align the needs of the individual with the rules of the community in which priesthood service was administered and where there had been a fixed order for centuries. They worked on developing the "self" through conversations with priests, and deepening religious life. ${ }^{30}$

In addition to its upbringing function, the Collegium Germanicum was an institution that encouraged and enhanced the education of priests. The pupils worked with their professors on consolidating their schoolwork at the Gregorian University. They had courses in public speaking, "pastoral theology" and "catechetics" administered by the headmaster or a priest. ${ }^{31}$

During Stepinac's stay at the Germanicum, the college was located in the Costanzi palace. The rector of Germanicum, in the years when Stepinac was his protégé, was Father Michael Hoffmann (1919-1925) and Father Rochus Rimmel (1925-1932). The students conducted their services in the church of St. John Berchmans, renamed in May 1926 as the church of St. Peter Canisius. In 1928 the Germanicum received a winter and summer college, which improved the standard of the students. That same year, 1928, the college had a visit from Wlodimir Ledóchowski, Superior General of the Society of Jesus, which was an important event for the students and their teachers. During weekends and holidays, students made pilgrimages to the Shrine of Our Lady of Mentorella and trips to the surrounding hills near Rome. Since the students did not go home, they spent their summer vacations and free days at the Villa San Pastore, about 30 kilometers from Rome. The students spent their Sundays at the San Sabba summer house. ${ }^{32}$ Stepinac spent his summer months in the villa San Pastore making furniture.

Alojzije Stepinac passed his final exams at the Gregorian University on July 1,1930. On October 10,1931, he received his doctoral diploma, which ended with the words: "May he use his acquired knowledge wisely and wholeheartedly for strengthening those authorities, which our gracious and great Lord has placed at the head of the administration of the Church and the State." The doctorate was recognized in Zagreb on December 18th. In the book that records the rector's impressions of Stepinac, the following was written: "He left the college in the summer of 1931; a priest of extraordinarily good significance from every point of view, sin-

$30 \quad$ Ibid., 74-75.

31 Ibid., 77-78.

32 Sirovec, Hrvati i Germanicum, 72. 
cerely devout and faithful in maintaining the college substance, very diligent in learning." 33

Stepinac's stay at the Germanicum college took place during the pontificate of Pope Pius XI, who had a major influence on developing religious sentiments among Catholics by issuing encyclicals on Catholic Action, the lay apostolate, Christ the King, Catholic marriage, social issues, agility in forming new parishes, and reconciliation with Mussolini. This also applied to the fellow Germanicum and Gregorian students. ${ }^{34}$ The encyclicals issued by Pius XI very directly determined the corpus of ideas and directions of work of Alojzije Stepinac upon returning to his home country. Their implementation in a nationally, religiously, and culturally complex state such as the Kingdom of Yugoslavia, inevitably led to conflict.

There is no doubt that during the years of schooling in Rome A. Stepinac had formed his opinions about communism and the "wrong doctrines of the modern age." They were based on the encyclicals of Pope Pius IX (Qui pluribus from 1846, Syllabus Errorum and Quanta Cura from 1864), Leo XIII (Quod apostolici muneris of 1878; on Freemasonry from 1884), Pius X (Pascendi dominici gregis from 1907) and Pius XI (Quadragesimo anno from 1931) and contained allegations that the doctrines of modern times (liberalism, socialism, communism) destroy faith and spread impiety and wickedness, deprive man and family of dignity, and jeopardize the security of Christian society and order. ${ }^{35}$

Obedience was a "specific" characteristic of the Jesuit order, whose members were the educators and professors of the Collegium Germanicum and the Gregorian University. Together with obedience went "discipline, discretion, adaptability, numbness, order, strict and consistent adherence to rules and duties". Particular attention was given to respecting the rules, for which there could be no compromise. Nor was there any compromise regarding the great "central idea" and the key content of all efforts, which was the implementation of the "Kingdom of Christ." These were efforts spread through the encyclical on Catholic Action promulgated by Pius XI, saying that "Christ needs to realize the kingdom of Heaven in the world", master human souls, and through them "the world and all lives" with the goal of achieving perfection "closer as possible to God." The Jesuits considered themselves to be such a spiritual army (elite) whose members were

33 Benigar, Alojzije Stepinac, 94-96.

34 Ibid., 77-78.

35 Many years later he would be influenced by the encyclical issued by Pope Pius XI Divini redemptoris from 1937. 
called upon to "blindly and wholeheartedly be placed in the service of the Church as the Kingdom of God on earth" and that in that kingdom they become "spreaders, pioneers, defenders, messengers, organizers..." The Jesuits always worked according to a preconceived plan, and that is also how they shaped their students, "conforming lower to higher, the means to the end, the individual to the principle, and according to the criterion of a conscious economy of power." Everyone under that program "had to come to a position where he was most capable." 36

Stepinac had gone to Rome filled with the accumulated discontent that bishops and clerics had toward the Yugoslav state, and he returned as an enemy of that state. The resistance of the state authorities to Roman Catholic endeavors for the church to keep its place in schools and continue to wield a decisive influence on the "upbringing" of youth, the painstaking negotiations over the concordat, in which the state had sought unsuccessfully to defend its vital interests, the conflicts that had arisen in the work of the Interim People's Representation over the centralist organization of the future state, the non-recognition of the 1921 Constitution and the disagreement over the ban on the use of the church for political purposes (the so-called Kanzelparagraf), the unyielding attitude that the church is the "basis of life" and that any limitation of its work is a display of intolerance, were articulated in the activities of bishops, clergymen, and the Catholic movement and Catholic Action into an intransigent attitude (conclusion) that the Yugoslav state was a liberal state in which the faith, and therefore, the nation, were endangered. This was accompanied by numerous fears regarding the ideology of liberalism, on which the Yugoslav state had been based, the proclaimed freedom of conscience of every individual and the laicization of society, religious equality, activity of Masonry, communist activities, the dominance of Orthodoxy, the centralization of state administration, the notion of a triple nation. Among their fears, there was particularly the one about "religious indifferentism," which escalated in the liberal Yugoslav state. All of this was shaped into a sense of vulnerability imposed on Catholic believers.

The Vatican press in Rome also wrote about all of the above issues during the years that Stepinac had spent there. These articles showed the

36 Katolički tjednik, br. 29, rujan 1940. 
position of the Roman Catholic Church in the Yugoslav state in a distinctly vulnerable light. They abounded with "news" about the banishment of the clergy from schools and educational institutions, the ban on congregations of the Heart of Mary, problems being made for the Eagles, the failure in concluding the concordat, the pressure to which Catholics were being exposed, and the threat to Catholicism. The Vatican press reported on the position of the Roman Catholic Church as a "tolerated religion" intended to be among the "minor religious sects." ${ }^{37}$

A particularly devastating blow to the Vatican was the Yugoslav Government's struggle for the college of St. Jerome. From that time there remains on record a statement by Pope Pius XI, pronounced in an allocution to the cardinals on December 14, 1925, that "in the Kingdom of Serbs, Croats and Slovenes, the heavens have not been spared from embarrassment"..$^{8}$ This attitude expressed by the head of the Roman Catholic Church indirectly formed the views of both the clergy and the students regarding the Yugoslav state.

Sometimes, the reports the Vatican printed were in collision with the established stereotypes and conclusions regarding the position of the Roman Catholic Church and its priests and believers in the Yugoslav state. For example, in late August 1926, the Vatican's official newspaper, L'Osservatore Romano, wrote about the "gigantic steps" that the Jesuit-led Eagle movement had made in the Yugoslav state. On that occasion, the paper used information from 1924 - the same time that A. Stepinac went off to pursue his studies - according to which the "Croatian Eagle Federation" had 170 male societies, with more than 8,000 members, and 70 women's organizations with 3,000 members. ${ }^{39}$ Regarding the Croatian "Eagles", of which A. Stepinac was an active member, the official Vatican newspaper in

37 Radmila Radić, "Alojzije Stepinac i odnos prema Srbima i pravoslavlju”, Zbornik radova s međunarodnog znanstvenog simpozijuma Nadbiskup Stjepinac i Srbi u Hrvatskoj u kontekstu Drugog svjetskog rata i poraća, Zagreb 24. studenog 2015, (Zagreb, 2016), 125-126; Lj. Dimić, N. Žutić, Rimokatolički klerikalizam u Kraljevini Jugoslaviji 19181941, (Beograd: Vojnoizdavački i novinski centar, 1992), 11-114.

38 Arhiv Srpske akademije nauka i umetnosti (Archives of Serbian Academy of Sciences and Arts - ASANU), Fond Viktora Novaka, br. 14474, nesređena građa, kut. 7, Izveštaj jugoslovenskog poslanika pri Vatikanu ministru spoljnih poslova Kraljevine SHS Vojislavu Marinkoviću od 20. aprila 1927. godine (Viktor Novak Fund, no. 14474, unclassified material, rack 7, Report of the Yugoslav envoy to the Vatican Minister of Foreign Affairs of the Kingdom of SHS Vojislav Marinkovic, dated April 20,1927).

39 ASANU, Fond Viktora Novaka, br. 14474/ podbroj 259, Iz Jugoslavije (razvoj katoličke delatnosti, naše informacije, tekst objavljen u glasilu Svete stolice L'Osservatore Romano 27. 8. 1926). 
Rome wrote that "they live, grow and thrive with the Catholic Church and for the Catholic Church." It said that their enemies called them the "guardians of the Pope." The Vatican press viewed them as the first Catholic organization, "which, since its very inception, has been subjected to the directives and leadership of its bishops." 40

The Vatican press issued regular broadcasts from the conferences of the Catholic Episcopate. In that sense, it reported on the bishops' opposition to the agricultural reform "which had been to the detriment of church land,"; to the country's aspirations to recognize "the validity of marriages that had been made unlawfully before heretical priests (Old Catholic Church)"; to the failure to protect the "Greek Catholics, who are in some places being targeted by the civil authorities"; to the disgusting "women's fashion" and in favor of imposing a ban on "indecently dressed women entering church." ${ }^{41}$

Contrary to the established stereotypes were also reports about the "new page" in the religious life of Catholics in Serbia, which was "turned" in 1918. According to information from the official newspaper of the Roman Catholic Church, L'Osservatore Romano, the church in Serbia was no longer regarded as something foreign. Indications of that were the strengthening of the church organization, an increase in the number of priests, the work of both male and female monastic orders, the organization of numerous public festivities, processions, and religious academies, the forming of Roman Catholic associations, and the unobstructed work of schools. ${ }^{42}$

The picture of everything that was happening in the Kingdom of Yugoslavia became particularly "dark" from the moment when new school laws were passed in December 1929. The Catholic press stigmatized the intentions of the Yugoslav educational authorities to have lay teachers teach religion in schools instead of priests. Its propaganda stressed that the new laws abolished all private Catholic schools. The "exclusion" of the church and priests from schools and the educational process, was considered inadmissible. The Vatican press also protested against the ban on school-based religious associations and organizations. It kept careful watch on the protests of the Roman Catholic bishops, clerical organi-

40 Ibid.

41 ASANU, Fond Viktora Novaka, br. 14474/ podbroj 259, Iz Jugoslavije (razvoj katoličke delatnosti, naše informacije, tekst objavljen u glasilu Svete stolice L'Osservatore Romano 29.10.1926).

42 ASANU, Fond Viktora Novaka, br. 14474/ podbroj 259, Iz Jugoslavije (razvoj katoličke delatnosti, naše informacije, tekst objavljen u glasilu Svete stolice L'Osservatore Romano 4.2.1929. i 9. 3.1929). 
zations and lay persons. It advocated the "rights" of the Roman Catholic Church, placing particular emphasis on the following: holding and opening religious schools; teaching religious solely by priests; church authorities having control over religious teaching. Special emphasis was placed on what the press in the Kingdom of Yugoslavia had been writing. The Vatican press registered attacks and insults against the Holy See, the pope, the papal nuncio, the Yugoslav bishops, and the Catholic Action. They denied the allegations interpreting the papal epistle on the "divine upbringing of youth" (Divini illius magistri), published on December 21, 1929, as an attempt to form a "united front," whose aim was to contribute to "dismembering the Yugoslav state." ${ }^{\prime 3}$

The Catholic press wrote about the dissatisfaction of the Croats with their position in the Yugoslav state, the fear of the Catholics from Serbian hegemony, the ban of Croatian "national culture", the proscribing of the Croatian name, of Catholicism that was being "targeted" by Greater Serbian ideology, the police regime in Belgrade, seeing Croatia as a Serbian colony, "which Belgrade exploits more than any metropolis in Europe its colonies," the oppression and abuse of the Croatian people. ${ }^{44}$

As for the attitude of the Jesuit Order - which had a crucial influence on the spiritual formation of Stepinac, during the years of his study at the Collegium Germanicum - toward the Serbian Orthodox Church and Orthodoxy, they openly pointed out that that "Byzantine Orthodoxy" was the cause of the Church's disunity in the Yugoslav state. Their thesis was that the Croats and the Serbs had been one religion until Eastern Orthodoxy divided them into two religions. Based on this, they argued with "justification" that "national disunity in our country, will cease to exist when the Eastern Orthodox Christians return to their religion, when they become Catholics, as the great majority of Croats are." In the Roman Catholic press, Eastern Orthodoxy was equated with Greater Serbian hegemony. ${ }^{45}$

The Yugoslav envoy to the Holy See also reported about the many factors that formed the Vatican's view about the Yugoslav state. In his reports, he pointed out that the Curia's mistrust of the Kingdom of Serbs, Croats, and Slovenes, was due in part to its fear of Russia and the connections that existed between Serbian and Russian Orthodoxy. The Vatican also firmly believed that the "Serbian Orthodox element was predomi-

43 The "exclusion" of the church and priests from schools and the educational process.

44 Juraj Batelja, Blaženi Alojzije Stepinac. Svjedok Evanđelja ljubavi, Vol. 1, (Zagreb: Postulatura blaženog Alojzija Stepinca, 2010), 43-44.

45 Cvitković, Ko je bio Alojzije Stepinac, 24-25. 
nant in the country," and that this "domination could become even more dangerous for the Catholic Church in the event of the restoration of Russia and its Orthodoxy." The highest-ranking Roman Catholic clergy shared the view that Serbia had caused the collapse of the Austro-Hungarian Empire and that the Serbs were hostile to the Holy See. This mistrust hampered mutual relations in the interwar years, and the Yugoslav bishops, as the envoy observed, "never made sufficient efforts to break this mistrust," but only "contributed to further reinforcing the Vatican's views." The mistrust toward the Yugoslav state was also prompted by Italy, as well as by the Italian prelates who, according to the Yugoslav envoy, "mainly served Italian aspirations and were imbued with hostile sentiments toward our people." A negative influence was also generated by the missionary activity of the Serbian Orthodox Church and Bishop Dositej in Czechoslovakia, which Vatican circles linked to official Belgrade. A similar effect was also produced by a part of the Catholics from the island of Vis converting to the Orthodox faith. The Vatican felt that the [Yugoslav] authorities were directly assisting the Old Catholics in Croatia. For its propaganda purposes, the Catholic press issued exaggerated complaints from converted believers that they were being persecuted by the authorities. In a similar vein were "reports" published by the Catholic press about the unequal financial position of the Roman Catholic Church and its clergy in the Yugoslav state. An unfavorable image of the Kingdom of Serbs, Croats, and Slovenes, was also created by the reports sent in by Ermenegildo Pellegrinetti, the papal Nuncio to Yugoslavia, who disliked Belgrade and whom the envoy described as being "more Italian than a servant of the church." According to the reports of the Yugoslav deputy to the Holy See, all of the aforementioned resulted in the Vatican's even greater mistrust toward the Yugoslav state. This "mistrust" was also an alibi for all the actions taken by the Vatican toward the Yugoslav state, which could not be considered friendly. ${ }^{46}$

The position that Stepinac held definitely enabled him to follow all the events in the country, but also to get a picture of these events solely based on the information coming from Roman Catholic sources and then fit that into the already formed "frame of mind" imprinted on him during his schooling under the influence of his Jesuit educators and teachers. Thus, all the voices that spoke about the conflicts between the church

46 ASANU, Fond Viktora Novaka, br. 14474, nesređena građa, kut. 7, Izveštaj jugoslovenskog poslanika pri Svetoj stolici N. Miroševića Sorga 20. aprila 1927. godine, (ASANU, Viktor Novak Fund, no. 14474, unspecified material, k-7, Report of the Yugoslav envoy to the Holy See N. Miroševic Sorga from April 20,1927). 
and the state contributed to an accumulation of dissatisfaction with the regime and the Yugoslav state.

Stepinac based his Anathema of liberalism, Freemasonry, Orthodoxy, Socialism, and Communism, on the views of the Roman Popes and the "teachings" that were passed on to him by "Jesuit priests" during his education at the Collegium Germanicum. In the coordinate system in his mind, religiousness was incompatible with Freemasonry and Communism, and Roman Catholicism, for dogmatic reasons, with Orthodox Christianity. According to his understanding of the world, embedded in him at the Collegium Germanicum, no dialogue with these "enemies of the church," was possible. In any case, A. Stepinac returned to his homeland, as his biographers pointed out, carrying within him the "blazing fire of Christ's love," respect for the pope, an immeasurable love for the Church and "Christian Rome." ${ }^{\prime 7}$ In the summer of 1931, in the college book that records the rector's impressions of Stepinac, the following was written: "He left (the College) in the summer of 1931; a priest of extraordinarily good significance from every point of view, sincerely devout and faithful in maintaining the college substance, very diligent in learning." ${ }^{\prime 8}$ This was the best recommendation with which A. Stepinac was accepted at the Kaptol.

By assuming the post of coadjutor archbishop, and after the death of Anton Bauer the post of Archbishop of Zagreb and President of the Bishops Conference, Alojzije Stepinac could do even more in implementing the ideas he accepted as a student of the Collegium Germanicum. In this work he was not alone, because Josip Srebrenič, the bishop of $\mathrm{Krk}^{49}{ }^{40-}$ sip Carević, the bishop of Dubrovnik, ${ }^{50}$ Viktor Burić, the bishop of Senj, ${ }^{51}$ and Franjo Salis Seewis, the auxiliary bishop of Zagreb, ${ }^{52}$ all belonged to the same circle of former students of this significant Jesuit college. If we

47 Batelja, Blaženi Alojzije Stepinac, 42.

48 Benigar, Alojzije Stepinac, 95; Batelja, Blaženi Alojzije Stepinac, 42.

49 Josip Srebrenič was a Germanicum student from 1902 to 1907. His duty as the bishop of Krk was from 1923 to 1966.

50 Josip Carević studied at the Germanic from 1903 to 1908 . He was the bishop of Dubrovnik between 1929 and 1940 .

51 Viktor Burić was a Germanicum student in 1917 and 1918. He was the bishop of Senj from 1935 to 1969. Pope Paul VI later appointed him as the first Archbishop of Rijeka-Senj.

52 He held this post from 1926 to 1967. 
know that Archbishop Josip Stadler and Auxiliary Bishop Josip Lang were also students of the Collegium Germanicum in the previous generation of high clergy, then we can say that the generation of Alojzije Stepinac carried on the continuity of the policy established by Archbishop Stadler at the First Croatian Catholic meeting of 1900, and the Jesuits implemented that policy toward the Yugoslav state from the moment of its inception.

Also former students of the Collegium Germanicum were other influential representatives of the Roman Catholic Church who, from their positions were able to contribute most directly to articulating the policy of Rome and the Roman Catholic Church in the Yugoslav state. This includes Josip Lončarić, one of the most influential Seniority members, ${ }^{53}$ Andrija Živković, professor and rector of the Catholic University of Theology in Zagreb, ${ }^{54}$ Stjepan Zimmermann, rector of the University of Zagreb, ${ }^{55}$ Dragutin Kniewald, professor and influential Catholic writer, ${ }^{56}$ Josip Marić, university professor, ${ }^{57}$ Stjepan Sakač, theologist of oriental church history, Croatian Germanist priest and advocate of the thesis on Slavic and Iranian origins of Croats, ${ }^{58}$ Antun Slamić, secretary of the Archbishop and Chancellor of the Archdiocese of Zagreb, ${ }^{59}$ Zlatko Kuntarić, legal expert and attorney, ${ }^{60}$ Vilim Nuk, Zagreb clergyman and head of Caritas, ${ }^{61}$ Nikola Kolaren, Zagreb clergyman, ${ }^{62}$ Matija Petlić, ${ }^{63}$ Petar Ivanšić, composer and professor of

53 Josip Lončarić was a Germanicum student from 1891 to 1898. He was the rector of the orphanages in Zagreb and one of the most influential members of the Seniority and Domagoj Society. He influenced the final decision of A. Stepinac for the priestly calling and was the manuductor at his "first mass" in Rome.

54 Andrija Živković was a Germanicum student from 1906 to 1913. At the Catholic Theological Faculty, he lectured on Moral Theology. He was rector from 1938-1940.

55 Zimmermann was a Germanicum student from 1907 to 1910. He held the function of the rector of the Catholic University Theology in Zagreb in the years 1923-1924.

56 Kniewald was a Germanicum student from 1908 to 1915. He taught at the University of Zagreb from 1921 to 1952 . He played a significant role in promoting the Catholic Action.

57 Marić was a Germanicum student from 1905 to 1911.

58 Sakač was a Croatian Germanicum priest as of 1937. That same year, he became professor at the Pontifical Orthopedic Institute in Rome. He was a Germanicum student from 1910 to 1915. For some time he was the rector of theology in Sarajevo.

59 Slamić was a Germanicum student from 1912 to 1919.

60 Kuntarić was a Germanicum student from 1917 to 1919. He was defense attorney for Stepinac, but also for many other priests in the processes conducted against them after 1945.

61 Vilim Nuk was a Germanicum student from 1918 to 1925.

62 Kolaren was a Germanicum student from 1921 to 1924.

63 Petlić was a Germanicum student from 1918 to 1923, when he moved to the College of St. Jerome in Rome. 
apologetics and dogmatics at the Catholic School of Theology in Djakovo, ${ }^{64}$ Franjo Šeper, influential representative of the Roman Catholic Church in Rome and for a period of time secretary of the Archbishop, ${ }^{65}$ and others.

All of them shared the collective awareness and "common spirit" of the Collegium Germanicum, an interconnectedness, tradition, and obligation of mutual communication and information sharing ("correspondence"). This was a kind of nucleus of the alliance of the Catholic elite, with solid connections to Rome, formed in the same way at the Collegium Germanicum and the Gregorian University, and ready to carry out every order from the Jesuits without any hesitation. Influential prelates, intellectuals, and priests were shaped by the spirit of the papacy, which sought to form trustworthy and important people of the church and the influence of the Jesuits, motivated to foster fanaticism and mobility among priests. This nucleus of the Catholic elite focused its activities on the "central areas" of work, particularly to missionary work on forming the future world and church elite (high schools, convents, seminaries, congregations, organizations and societies of Catholic Action, scientific institutions, publishing, spiritual exercises, sermons, missions, ceremonies, spiritual guidance...). Initiative, mindfulness of responsibility, blind obedience to the authorities, fanaticism in work, have undoubtedly existed among the students of the Collegium Germanicum, but also the tendency to respect authority, have permanent protectors and leaders, and accept assignments from their mentors in Rome. As far as the pupils of the Collegium Germanicum, and with them A. Stepinac, were concerned, their enduring fixation on Rome was unquestionable.

\section{Sources and Literature}

\section{Unpublished sources}

- $\quad$ Arhiv Srpske akademije nauka i umetnosti. Fond Viktora Novaka.

\section{Literature}

- $\quad$ Alexander, Stella. The Triple Myth: a Life of Archbishop Alojzije Stepinac. Boulder/New York: Columbia University Press, 1987.

- Batelja, Juraj. Blaženi Alojzije Stepinac. Svjedok Evanđelja ljubavi, Vol. 1. Zagreb: Postulatura blaženog Alojzija Stepinca, 2010.

64 Ivanšić was a Germanicum student at the same time as Stepinac, from 1925 to 1931.

65 Franjo Šeper was a Germanicum student in the same generation as Stepinac, from 1924 to 1931. 
- $\quad$ Beluhan, E. „Da li je kardinal Stepinac bio zasut minom na bojištu?“ Stepinac mu je ime, knj. I. Zagreb: Kršćanska sadašnjost, 1991.

- $\quad$ Benigar, Aleksa. Alojzije Stepinac. Rim: Zajednica izdanja Ranjeni labud, 1974.

- $\quad$ Cvitković, Ivan. Ko je bio Alojzije Stepinac. Sarajevo: Oslobođenje, 1986.

- Gavranović, Zvonimir. In Serch of Cardinal Stepinac. A Complete Biography. Zagreb: Kršćanska sadašnjost, 2011.

- Dimić, Ljubodrag, Nikola Žutić. Rimokatolički klerikalizam u Kraljevini Jugoslaviji 1918-1941. Beograd: Vojnoizdavački i novinski centar, 1992.

- $\quad$ Harris, Robin. Stepinac, njegov život i vreme. Zagreb: Školska knjiga, 2016.

- Horvat, Vladimir. Kardinal Alojzije Stepinac - mučenik za ljudska prava. Zagreb-Samobor-Krašić: Meridijani, 2008.

- Leitgö, Martin. Vom Seelenhirten zum Wegführer. Sondirungen zum Bischöflichen Selbstverständnis im 19. und 20. Jahrhundert. Die Antrittshirtenbriefe der Germaniker bischöfe (1837-1962). Rim: Herder, 2004.

- Leposavić, Petar S. Papstvo. Beograd: Izdavački grafički atelje „M“, 2005.

- Radić, Radmila. "Alojzije Stepinac i odnos prema Srbima i pravoslavlju”. Zbornik radova $s$ međunarodnog znanstvenog simpozijuma Nadbiskup Stjepinac i Srbi u Hrvatskoj u kontekstu Drugog svjetskog rata i poraća, Zagreb 24. studenog 2015. Zagreb, 2016.

- Sakač, Stjepan. „Barbara Stepinac i svećeničko zvanje njenog Alojzija“. Stepinac mu je ime, knj. I. Zagreb: Kršćanska sadašnjost, 1991.

- Schmidt, Peter. Das Collegium Germanicum in Rom und die Germaniker. Zur Funktion eines römischen Ausländerseminars (1552-1914). Tübingen: Max Niemeyer Verlag, 1984.

- $\quad$ Sirovec, Stjepan. Hrvati i Germanicum. Zagreb: Filozofsko-teološki institut Družbe Isusove, 2004.

Newspapers

- Danas

- Katolički tjednik 


\section{Summary}

The Collegium Germanicum was a papal Jesuit college in Rome for the upbringing and education of priests. At this college Alojzije Stepinac spent seven years (1924-1931) and obtained two doctoral degrees - in theology and philosophy. Stepinac went to Rome filled with the accumulated discontent that bishops and clerics had toward the Yugoslav state and returned as an enemy of that state. The years of his schooling were marked by the Roman Catholic Church's dissatisfaction with the Yugoslav state, which did not want the church to retain its place in the school system and continue to influence the education of young generations. Relations between the church and the state were also marked by painstaking negotiations over the concordat. Reports about the conflicts between the church and the state reached Stepinac and contributed to his mistrust of the state. The teachings of the popes of Rome and "Jesuit fathers" during his studies at the Collegium Germanicum filled him with loathing for liberalism, Freemasonry, Eastern Orthodoxy, socialism, and communism. He was educated in the spirit of unquestioning submission to Rome and respect for authority. In addition to Stepinac, many other influential representatives of the Catholic Church in Yugoslavia were Germanicum students. All of them shared the collective awareness and "common spirit" of the Collegium Germanicum, an interconnectedness, tradition, and obligation of mutual communication and information sharing ("correspondence"). This was a kind of nucleus of the alliance of the Catholic elite, with strong connections to Rome and ready to carry out every command from the Jesuits without any hesitation. 


\title{
Резиме
}

Љубодраг Димић

\section{Алојзије Степинац питомац Папског завода Германикум (1924-1931)}

\begin{abstract}
Апстракт: Седмогодишњи боравак у Папском заводу Германикум (1924-1931) имао је велики утицај на идеолошко-верско сазревање Алојзија Степинца. Школовање у овој установи коју су водили језуити одвијало се у условима појачане клерикализације хрватског друштва и сукоба Католичке цркве и југословенске државе.
\end{abstract}

Кључне речи: Алојзије Степинац, Папски завод Германикум, Римокатоличка црква, језуити

Collegium Germanicum је био папски, језуитски завод за свештеничко васпитање и образовање у Риму. На њему је Алојзије Степинац провео седам година (1924-1931) и стекао два доктората - из теологије и филозофије. У Рим је кренуо испуњен акумулираним незадовољством које су бискупи и клерикалци имали према југословенској држави, а из њега се вратио као непријатељ те државе. Године његовог школовања обележило је незадовољство Римокатоличке цркве југословенском државом, која није желела да црква задржи своје место у школском систему и да и даље утиче на образовање младих нараштаја. Односе цркве и државе су обележили и мукотрпни преговори око конкордата. Вести о сукобима цркве и државе су долазиле до Степинца и доприносиле његовом неповерењу у државу. Учења римских папа и „отаца исусоваца“ током школовања у Германикуму формирала су у њему одбојност према либерализму, масонству, православљу, социјализму и комунизму. Образован је у духу беспоговорне потчињености Риму и поштовања ауторитета. Осим Степинца, питомци Германикума су били и други утицајни представници Католичке цркве у Југославији. Све њих повезивала је групна свест и „заједнички дух“ Германикума, међусобна повезаност, традиција, али и обавеза међусобног комуницирања и информисања („кореспонденција“). У питању је било својеврсно језгро савеза католичке елите, чврстим везама повезано са Римом и спремно да беспоговорно изврши сваки налог који од језуита добије. 